\title{
PERSEPSI PETANI TERHADAP TEKNOLOGI INFORMASI DAN PENGARUHNYA TERHADAP PERILAKU PETANI PADA RISIKO HARGA KENTANG
}

\section{FARMER PERCEPTION OF INFORMATION TECHNOLOGY AND ITS EFFECT ON FARMER BEHAVIOR AT POTATO PRICE RISK}

\author{
Wenny Mamilianti ${ }^{1)}$ \\ ${ }^{1)}$ Program Studi Agribisnis, Fakultas Pertanian, Universitas Yudharta Pasuruan \\ Email: wennymfp@yudharta.ac.id
}

\begin{abstract}
ABSTRAK
Tujuan dari penelitian ini adalah (1) mengetahui persepsi petani kentang terhadap penggunaan teknologi informasi dan (2) menganalisis pengaruh penggunaan teknologi informasi dan faktor-faktor lain terhadap perilaku petani pada risiko harga kentang. Penelitian dilakukan di Kabupaten Pasuruan dengan responden berjumlah 183 orang. Metode analisis yang digunakan adalah metode tabulasi data untuk menggambarkan persepsi petani terhadap teknologi informasi. Analisis untuk mengetahui pengaruh teknologi informasi dan faktor lain terhadap risiko produksi adalah analisis regresi logit. Hasil menunjukkan bahwa teknologi informasi bermanfaat dalam kegiatan usahatani kentang khususnya untuk informasi harga dan pasar. Faktor-faktor yang berpengaruh terhadap sikap petani pada risiko harga adalah usia, harga sebelumnya, harga saat ini dan penggunaan teknologi informasi. Teknologi informasi sangat bermanfaat bagi petani dataran tinggi khususnya petani kentang yang terbatas akan akses informasi sehingga perlu adanya penyediaan sarana prasarana yang memadai untuk kemudahan penggunaan teknologi informasi. Perlu ada sarana yang menyediakan informasi harga dan pasar secara terbuka untuk petani.
\end{abstract}

Kata kunci: kentang; persepsi petani; risiko harga; teknologi informasi

\begin{abstract}
Purpose of this study is (1) to determine the perception of potato farmers on the use of information technology, and (2) to analyze the effect of the use of information technology and other factors on farmer's behavior on the potato price risk. The study was conducted in Pasuruan Regency with 183 respondents. The analytical method used is the data tabulation method to describe farmers' perceptions of information technology. Analysis to determine the effect of information technology and other factors on production risk is logit regression analysis. The results show that information technology is beneficial in potato farming activities especially for price and market information. The factors that influence the attitude of farmers to price risk are age, previous prices, current prices and the use of information technology. Information technology is very beneficial for highland farmers, especially potato farmers, who are limited in access to information, so there is a need to provide adequate infrastructure to facilitate the use of information technology. There needs to be a means that provides information on prices and markets openly for farmers.
\end{abstract}

Keywords: farmer's perception; information technology; price risk; potato 


\section{PENDAHULUAN}

Globalisasi telah mempercepat perkembangan pengetahuan dan teknologi di semua sektor, termasuk perkembangan teknologi informasi. Era saat ini disebut era revolusi industri 4.0 atau era milenial di mana kebutuhan terhadap teknologi informasi terus berkembang. Teknologi informasi adalah sebuah teknologi yang dapat mempemudah kinerja manusia karena fungsinya bisa membuat, mengubah, menyimpan, mengkomunikasikan dan menyebarkan informasi. Kebutuhan untuk mengembangkan mekanisme yang efektif dalam komunikasi dan penyebaran teknologi di bidang pertanian misalnya, para petani membutuhkan hal tersebut agar usahatani berkembang dan kesejahteraan meningkat (Burman, et al., 2013).

Penggunaan teknologi informasi oleh petani dapat meningkatan kemampuan dan kualitas petani dalam mengelola usahatani. Beberapa penelitian menyebutkan bahwa penggunaan teknologi informasi dapat meningkatkan kemampuan manajerial petani. Dasli, et al. (2015) menemukan bahwa setelah menggunakan telepon genggam petani dapat berkomunikasi dengan konsumen meskipun dengan jarak yang jauh, sehingga biaya transportasi lebih efisien dan negosiasi lebih baik dan cepat. Fangohoi, et al. (2018) menyebutkan bahwa persepsi petani positif pada ekstensi dunia maya mengenai variabel manfaat, kompleksitas, dan kenyamanan. Amin (2014) menjelaskan bahwa semakin tinggi persepsi petani terhadap teknologi informasi, semakin tinggi pula perilaku petani dalam pengembangan kegiatan usahataninya.

Pemanfaatan teknologi informasi di sektor pertanian sangalah penting, karena kegagalan penyebaran informasi yang dibutuhkan oleh petani menunjukkan rendahnya produktifitas usahatani (Burman, et al., 2013). Ketersediaan media informasi yang terbatas menyebabkan kegagalan dalam penyebaran teknologi inovasi di bidang pertanian sehingga produksi kurang maksimal, yang selanjutnya menyebabkan penurunan suplai produk, kerawanan pangan dan penurunan perekonomian pedesaan. 
Sanggetha, et al. (2015) menemukan bahwa teknologi informasi memainkan peran penting dalam menjembatani kesenjangan informasi pertanian di daerah pedesaan. Informasi-informasi di bidang pertanian antara lain teknologi budidaya pertanian, hasilhasil penelitian, peraturan pemerintah dan perubahan iklim.

$$
\text { Saxenta, et al. }
$$

menjelaskan bahwa teknologi informasi memainkan peran penting dalam menyediakan informasi terkini tentang pengendalian hama penyakit sejak dini untuk menghindari kegagalan panen. Selain itu informasi terkait tentang harga pasar baik harga output input, pengembangan jejaring kelembagaan dan tren konsumen akan meningkatkan posisi negosiasi petani dimana memungkinkan petani membuat keputusan yang lebih baik.

Informasi tentang harga pasar dan kecenderungan konsumen penting diperoleh petani karena fluktuasi harga dan pergerakan dalam pemasaran komoditi pertanian adalah sumber terjadinya risiko harga. Hal ini dijelaskan oleh Kimura, et al. (2010) bahwa risiko harga berhubungan dengan kegiatan pemasaran. Fluktuasi harga yang terus bergerak secara tajam dapat merugikan petani, karena tidak adanya kepastian berapa jumlah keuntungan yang didapat. Jika harga yang lebih rendah dari yang diharapkan maka petani akan menanggung kerugian, dan kesulitan untuk merencanakan musim tanam selanjutnya karena modal terbatas. Fluktuasi harga sering terjadi pada komoditi sayuran seperti kentang, sehingga risiko yang ditanggung petani sayuran akan lebih tinggi dari pada tanaman lainnya Menurut Benni, et al. (2014) bahwa besarnya risiko harga juga tergantung dari jenis komoditi. Harga hari ini belum tentu sama dengan harga minggu depan. Oleh karena itu jika informasi pasar diperoleh petani dengan cepat dan akurat akan menguntungkan petani. Pada penelitian ini meanggunakan teknologi informasi sebagai variabel dalam analisisnya. Menurut Duong, et al. (2019) penelitian-penelitian tentang risiko masih sedikit yang melihat pengaruh penerapan teknologi terhadap risiko dalam analisisnya. 
Penelitian ini mengambil data usahatani kentang. Usahatani kentang di Indonesia pada umumnya dilakukan di dataran tinggi karena faktor agroklimat mendukung syarat tumbuh tanaman kentang. Dataran tinggi dengan topografi berbukit serta kemiringan lahan yang tajam menjadi hambatan petani sulit memanfaatkan teknologi informasi karena kondisi tersebut menghalangi masuknya sinyal internet. Pemerintah atau pihak terkait untuk membangun infrastruktur yang mendukung membutuhkan biaya cukup tinggi. Kondisi topografi dataran tinggi menyulitkan petani dalam distribusi input output, informasi harga pasar yang diharapkan tidak bisa diakses dengan cepat dan akurat sehingga banyak petani merasa dipermainkan tengkulak atau pedagang pengepul. Kemajuan teknologi informasi saat ini sangat menguntungkan bagi pelaku usaha yang menguasainya. Petani kentang di dataran tinggi tidak semua menguasai teknologi informasi. Hal ini dibuktikan bahwa belum semua petani menggunakan teknologi ini.
Permasalahan utama dalam penelitian ini adalah persepsi petani terhadap teknologi informasi dan pengaruhnya terhadap perilaku petani pada risiko harga. Untuk menjawab permasalahan tersebut maka dilakukan penelitiann untuk mengetahui persepsi petani kentang terhadap teknologi informasi dan menganalisis pengaruhnya terhadap perilaku petani pada risiko harga.

\section{METODE PENELITIAN}

Penelitian ini diakukan di Kabupaten Pasuruan dengan pertimbangan bahwa Kabupaten Pasuruan adalah sentra produksi kentang di Jawa Timur. Kecamatan yang menjadi sentra produksi kentang di Kabupaten Pasuruan adalah Kecamatan Tosari, Tutur dan Puspo. Kecamatan yang menjadi lokasi penelitian adalah Kecamatan Tosari dengan pertimbangan kecamatan ini produsen kentang tertinggi di Kabupaten Pasuruan. Data dikumpulkan pada bulan JuliDesember 2018. Jenis data yang digunakan adalah data cross section yang diambil melalui wawancara 
langsung dengan responden.

Penentuan sampel dilakukan secara random sampling dengan jumlah sampel 183 petani.

Analisis yang digunakan untuk mendiskripsikan persepsi petani terhadap penggunaan teknologi informasi adalah analisis tabulasi data. Tabulasi data digunakan untuk menggolongkan, mengurutkan, menyederhanakan data.

Pengukuran perilaku petani terhadap risiko harga menggunakan model Just and Pope (1979) dengan pendekatan maksimalisasi utiliti. Model tersebut adalah:

$$
p^{e}=p e^{\eta}
$$

dimana $p^{e}=$ harga output yang diharapkan

$$
\begin{aligned}
& p=\text { harga output actual } \\
& \eta=\text { error term yang }
\end{aligned}
$$

menggambarkan ketidakpastian harga output

Dengan asumsi $E\left[e^{\eta}\right]=1$ maka keuntungan yang diharapkan dapat dirumuskan sebagai berikut $\pi^{e}=p^{e} y-w x=p f(x, z)-w^{\prime} x+$ $p f(x, z)\left(e^{\eta}-1\right)$
Sehingga keuntungan yang diharapkan yang dinormalkan sebagai berikut.

$$
\begin{aligned}
& \frac{\pi^{\varepsilon}}{p}=f(x, z)-\widetilde{W}^{\prime} x+f(x, z)\left(e^{\eta}-1\right) \\
= & \mu_{\pi}+f(x, z) w_{1}
\end{aligned}
$$

dimana: $w_{1}=\left(e^{\eta}-1\right)$

Syarat turunan pertama (FOC) untuk memaksimalkan utilitas yang diharapkan sebagai berikut

$$
\begin{aligned}
& E\left[U ^ { \prime } ( \frac { \pi ^ { e } } { p } ) \left(f_{j}(x, z)-\widetilde{w}_{j}+\right.\right. \\
& \left.\left.\left.f_{j}(x, z) \omega_{1}\right)\right)\right]=0 \forall j=1, \ldots J
\end{aligned}
$$

Kondisi tersebut bisa ditulis sebagai:

$$
\mathrm{f}_{\mathrm{j}}\left(1+\theta_{2}\right)=\tilde{\mathrm{w}}_{\mathrm{j}}
$$

dimana:

Bila $\theta_{2}>0$ maka $\mathrm{f}_{\mathrm{j}}\left(1+\theta_{2}\right)>\tilde{\mathrm{w}}_{\mathrm{j}}$, $\mathrm{f}_{\mathrm{j}}$ harus menurun supaya $\mathrm{f}_{\mathrm{j}}\left(1+\theta_{2}\right)=\tilde{\mathrm{w}}_{\mathrm{j}}$, atau $\mathrm{x}_{\mathrm{j}}$ meningkat. Oleh karena itu bila $\theta_{2}>0$ maka produsen risk taker.

Bila $\theta_{2}<0$ maka $\mathrm{f}_{\mathrm{j}}\left(1+\theta_{2}\right)<\tilde{\mathrm{w}}_{\mathrm{j}}$, $\mathrm{f}_{\mathrm{j}}$ harus meningkat supaya $\mathrm{f}_{\mathrm{j}}\left(1+\theta_{2}\right)=\tilde{\mathrm{w}}_{\mathrm{j}}, \quad$ atau $\quad \mathrm{x}_{\mathrm{j}}$ menurun. Oleh karena itu bila $\theta_{2}<0$ maka produsen risk averse.

Analisis untuk mengatahui pengaruh teknologi informasi dan 
faktor lain terhadap perilaku petani pada risiko harga adalah analisis regresi logit. Perilaku menghadapi risiko dapat diklasifikasikan menjadi tiga kategori yaitu sebagai berikut (Robison dan Barry, 1987): risk averse, risk neutral dan risk seeker. Namun pada penelitian ini hanya dibedakan menjadi dua yaitu risk averse dan risk seeker. Hal ini berdasarkan data dan analisis menggunakan metode Just and Pope (1979) bahwa petani di lokasi penelitian digolongkan menjadi risk averse dan risk seeker. Untuk menentukan variabel pembanding maka risk seeker diwakili oleh variabel dummy 1 dan 0 untuk risk averse. Menentukan faktor-faktor yang mempengaruhi perilaku petani terhadap risiko, variabel sosial ekonomi dan penggunaan teknologi informasi sebagai variabel independen dan perilaku terhadap risiko sebagai variabel dependen. Penggunaan regresi logit sesuai dengan penelitiann ini.

Analisis regresi logistik kemudian ditetapkan sebagai:

$$
\begin{array}{lc}
e^{z}=\frac{p i}{1-P i} & \beta i=\text { koefisien variabel i } \\
z=\beta 0+\beta 1 X 1+\beta 2 X 2++\beta 3 X 3+\beta 4 X 4+\beta 5 X 5+\beta 6 X 6+\beta 7 X 7+\varepsilon^{i}
\end{array}
$$

$P^{i}=$ nilai probabilitas

$\beta i=$ koefisien variabel $\mathrm{i}$

$\varepsilon i=$ stchastic error

Persamaan 1 dapat ditulis agi dalam bentuk:

$P i=\frac{e^{x}}{1-e^{x}}$

$(1-P i)=\frac{1}{1-a^{2}}$

Sehingga rasio peluang adalah $:\left(\frac{p_{i}}{1-p_{i}}\right)$

Tes statistik mengenai model logit adalah Uji Hosmer dan Lemeshow untuk menguji apakah probabilitas yang diprediksi cocok dengan yang diamati (Meyers, et al., 2013). Diharapkan bahwa tes akan menunjukkan perbedaan yang tidak signifikan antara probabilitas yang diamati dan yang diprediksi. Koefisien individual logit diuji menggunakan uji Wald. Hipotesis yang di nyatakan adalah:

$\mathrm{HO}=\beta \mathrm{i}=0$

$\mathrm{H} 1=\beta \mathrm{i} \neq 0$

Uji statistik yang digunakan adalah:

$W i=\left(\frac{\beta i}{S E_{\beta i}}\right)^{2}$

Dimana : 
Deskripsi variabel yang digunakan

yang diharapkan ada dalam tabel 1.

dalam model logit dan tanda-tanda

\begin{tabular}{|c|c|c|c|c|}
\hline No & Variabel & $\begin{array}{l}\text { Tipe } \\
\text { data }\end{array}$ & Pengukuran & $\begin{array}{l}\text { Ekspektas } \\
\text { i tanda }\end{array}$ \\
\hline 1 & Usia petani & Rasio & $\begin{array}{l}\text { Usia petani, satuan variabel } \\
\text { adalah tahun. }\end{array}$ & $+/-$ \\
\hline 2 & Pendidikan & Rasio & $\begin{array}{l}\text { Lama petani menempuh } \\
\text { pendidikan diukur dengan } \\
\text { tahun }\end{array}$ & $+/-$ \\
\hline 3 & $\begin{array}{l}\text { Produksi } \\
\text { sebelumnya }\end{array}$ & Rasio & $\begin{array}{l}\text { Jumlah produksi sebelum } \\
\text { panen yang terkahir diukur } \\
\text { dengan kg }\end{array}$ & + \\
\hline 4 & Harga sebelumnya & Rasio & $\begin{array}{l}\text { Harga output sebelum panen } \\
\text { yang terakhir diukur dengan } \\
\text { Rp }\end{array}$ & + \\
\hline 5 & Harga sekarang & Rasio & $\begin{array}{l}\text { Harga output panen yang } \\
\text { terkahir }\end{array}$ & + \\
\hline 6 & Pekerjaan off farm & Nominal & $\begin{array}{l}\text { Petani memiliki pekerjaan lain } \\
\text { diluar pertanian bernilai } 1 \text { dan } \\
0 \text { untuk tidak memiliki }\end{array}$ & - \\
\hline 7 & Teknologi informasi & Nominal & $\begin{array}{l}\text { Menggunakan teknologi } \\
\text { informasi bernilai } 1 \text { dan } 0 \text { jika } \\
\text { tidak menggunakan }\end{array}$ & + \\
\hline
\end{tabular}

\section{HASIL DAN PEMBAHASAN}

\section{Karakteristik Responden}

Karakteristik responden

berdasarkan usia dapat dilihat pada gambar 1. Usia responden sebagian besar $(45 \%)$ berada pada rentang 30 40 tahun. Sedangkan usia di atas 50 tahun sebesar 21\%. Hal ini memperlihatkan bahwa petani responden adalah petani muda yang masih produktif. Petani muda memiliki tenaga yang lebih kuat, usia muda memungkinkan memiliki kesempatan untuk menambah ilmu pengetahuan dan penerapan teknologi lebih besar.

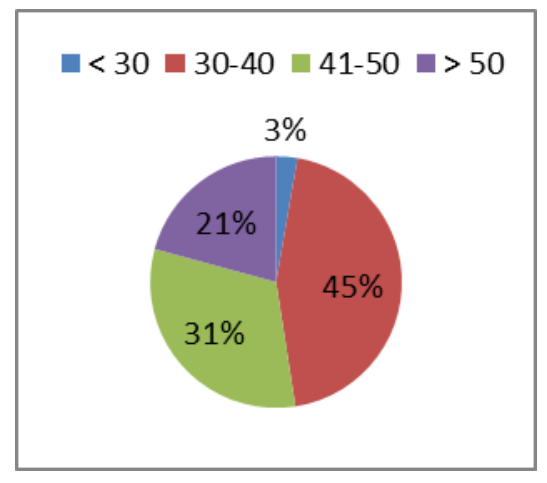

Gambar 1. Distribusi Responden Berdasarkan Usia 
Tingkat pendidikan petani responden tergolong rendah karena sebagian besar berpendidikan Sekolah Dasar, yaitu 43\% (Gambar 2). Tingkat pendidikan akan berpengaruh terhadap penerapan teknologi, di mana petani berpendidikan lebih tinggi akan memiliki kemampuan menerapkan teknologi lebih besar.

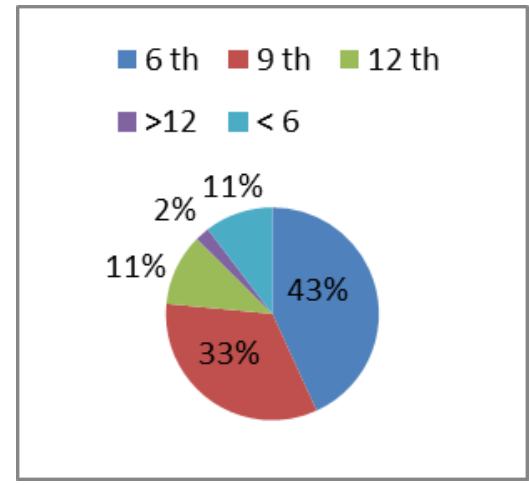

Gambar 2. Distribusi Tingkat Pendidikan Responden

Petani responden selain pekerjaan utama petani berjumlah $41 \%$ (Gambar 3). Jenis pekerjaan yang ditekuni selain petani yaitu: pedagang, pekerja jasa (pemandu wisata), pekerja sektor industri dan perangkat desa. Pekerjaan ini dilakukan saat tidak mengerjakan usahatani atau berbagi pekerjaan dengan anggota keluarga lainnya. Biasanya sang istri yang melakukan pekerjaan bertani.

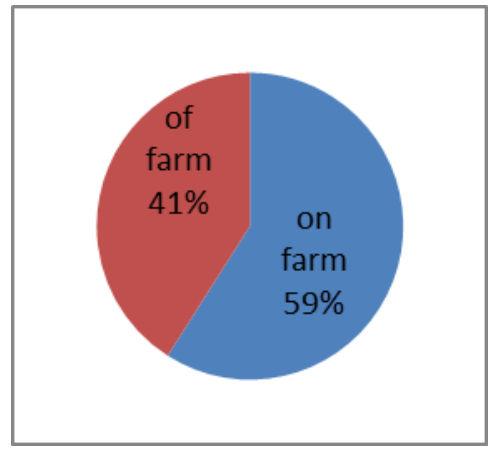

Gambar 3. Perbandingan pekerjaan di luar pertanian

Petani responden yang telah menggunakan teknologi informasi sebesar 52\% (Gambar 4). Teknologi informasi yang biasa digunakan adalah Facebook, Instagram, Watshap dan beberapa hanya menggunakan untuk SMS dan telepon. Penggunaan google untuk mendapatkan informasi lainnya dilakukan hanya jika membutuhkan dan sebagian besar petani responden yang menggunakan teknologi informasi mengakses informasi pertanian lewat google. Penggunaan Facebook 89 orang, Watshap 42 orang, IG 15 orang dan SMS/telpon 95 orang. Sebanyak $48 \%$ tidak menggunakan teknologi informasi dengan alasan tidak memiliki handphone dan tidak bisa menggunakannya. 


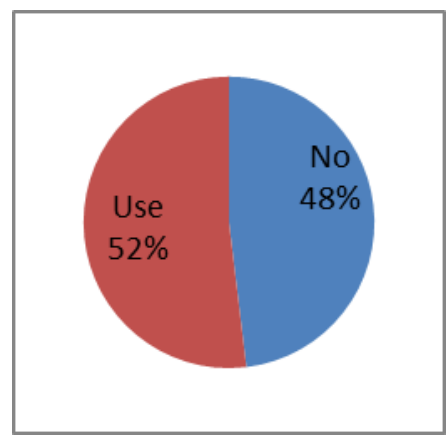

Gambar 4. Jumlah Penggunaan Teknologi Informasi oleh Petani Responden

\section{Persepsi Petani Terhadap Teknologi Informasi}

Tabel 2. Penilaian Persepsi terhadap Teknologi Informasi

\begin{tabular}{llll}
\hline INDIKATOR & ATRIBUT & JUMLAH & PERSENTASE \\
\hline Kemudahan & Sinyal kuat & 25 & 26,32 \\
Mengakses & Sinyal sedang & 27 & 28,42 \\
& Sinyal sulit & 43 & 45,26 \\
Kemanfaatan & Bermanfaat & 56 & 58,95 \\
Terhadap Usahatani & Kurang bermanfaat & 39 & 41,05 \\
Pengetahuan tentang & Baik & 31 & 32,63 \\
Aplikasi & Sedang & 45 & 47,36 \\
& Kurang & 19 & 20 \\
Frekuensi & Sering & 31 & 32,63 \\
Penggunaan & Sedang & 38 & 40 \\
& Kurang & 26 & 27,36 \\
Ketersediaan & Baik & 23 & 24,21 \\
Infrastruktur & Sedang & 13 & 13,68 \\
& Kurang & 59 & 62,11 \\
Peran Pemerintah & Baik & 32 & 16,84 \\
untuk Sosialisasi & Sedang & 16 & 33,68 \\
& Kurang & 47 & 49,47 \\
Sumber Informasi & Diri sendiri & 25 & 26,31 \\
Penggunaan & Teman & 43 & 45,26 \\
Teknologi Informasi & PPL/Kelompok & 27 & 28,42 \\
\hline
\end{tabular}

Sumber: Analisis data primer 2018

Dari Tabel 2 dapat dilihat respon petani terhadap keberadaan teknologi informasi. Sebagian besar petani merespon dengan sulitnya mendapatkan sinyal. Hal ini dapat dipahami karena kondisi lokasi yang berbukit dan berlereng sehingga sinyal sulit didapatkan. Dengan sulitnya 
sinyal akan mempengaruhi penggunaan teknologi informasi. Frekuensi penggunaan yang melakukan setiap hari masih kurang dan petani lebih banyak menggunakan jika diperlukan saja. Alasan lain adalah sebagian besar waktu petani digunakan untuk bekerja di lahan pertanian. Petani di lokasi penelitian bekerja mulai jam 5 pagi sampai jam 11 siang dan terkadang juga dilanjutkan sore hari jam 2 sampai jam 5 sore.

Petani mengetahui adanya teknologi teknologi informasi sebagian besar dari teman dan PPL atau kelompok tani, namun karena tingkat pendidikan masih rendah mempengaruhi pengetahuan tentang teknologi informasi. Ketersediaan infrastruktur di sekitar lokasi penelitian yang mendukung adanya akses internet juga masih terbatas. Pembangunan provider juga belum masuk ke wilayah penelitian karena sulitnya medan yang berbukit dan berlereng tajam. Ada beberapa provider yang telah membangun infrastruktur namun masih di luar kecamatan dengan jarak $10 \mathrm{~kg}$ dan berada di ketinggian lebih rendah. Peran pemerintah di mana hal ini adalah Dinas Pertanian dan PPL sebagai petugas lapangan, dinilai masih kurang memberikan sosialisasi tentang penggunaan teknologi informasi. Penyebabnya adalah terbatasnya tenaga PPL di lokasi penelitian dibandingkan dengan jumlah kelomppok tani dan petani yang ada.

Persepsi petani tentang teknologi informasi seperti disajikan pada tabel 2 , memberikan informasi bahwa petani sudah sebagian menggunakan teknologi informasi meskipun masih sebatas media sosial. Petani menyatakan bahwa penggunaan teknologi informasi memberikan manfaat bagi usahataninya. Kemanfaatan tersebut terutama untuk infomasi harga, pasar dan teknologi budidaya yang terbaru.Mereka mendapat informasi dari sesama petani dan atau dari beberapa website resmi pemerintah. Selain untuk informasi mereka juga menggunakan untuk alat komunikasi dengan sesama petani, pedagang, pemerintah dan keluarga sehingga kinerja mereka bisa lebih efisien dari segi waktu dan biaya. 
Pengaruh Teknologi informasi dan faktor-faktor lain terhadap perilaku petani pada risiko harga.

Tabel 3. Hasil Analisis Logit

\begin{tabular}{lcccc}
\hline Variabel & Koefisien & Wald & Sig. & $\operatorname{Exp} \beta$ \\
\hline Usia & 0,196 & 17,041 & 0,000 & 1,217 \\
Pendidikan & 0,093 & 0,476 & 0,490 & 1,098 \\
Produksi-1 & 0,000 & 0,158 & 0,691 & 1,000 \\
Harga-1 & 0,004 & 22,416 & 0,000 & 1,004 \\
Harga-0 & 0,001 & 5,124 & 0,024 & 0,999 \\
OffFarm & $-0,195$ & 0,096 & 0,757 & 0,823 \\
Teknologi informasi & 2,923 & 21,921 & 0,000 & 18,595 \\
Constant & 28,537 & 24,478 & 0,000 & 0,000 \\
& & & & \\
\hline
\end{tabular}

Hasil analisis pada Tabel 3 menunjukkan bahwa ada 4 faktor yang berpengaruh positif dan signifikan terhadap penerimaan risiko harga, yaitu usia, harga kentang sebelumnya, harga saat ini dan penggunaan teknologi informasi. Dari keempat faktor tersebut, penggunaan teknologi informasi memberikan pengaruh tertinggi dalam kemungkinan penerimaan terhadap risiko harga. Ini menunjukkan bahwa penggunaan teknologi informasi memberikan manfaat dalam pengelolaan usahatani kentang khususnya tentang informasi pasar.

Petani cenderung memanfaatkan teknologi informasi untuk mencari infomasi harga dan pasar baik lewat media sosial ataupun berita di internet. Hal ini karena informasi yang berhubungan dengan pasar dan harga komoditi pertanian jarang disajikan di media elektronik seperti radio dan televisi. 


\begin{abstract}
Kecepatan mendapatkan informasi harga dan pasar memberikan ketenangan pada petani dan lebih tepat mengambil keputusan dalam pemasaran. Petani juga menjalin kerjasama dengan kelompok tani lain melalui medsos sehingga lebih banyak informasi harga dan pasar yang didapat.

Pengaruh positif dan signifikan teknologi informasi terhadap perilaku petani terhadap risiko harga juga menunjukkan bahwa petani lebih cenderung berperilaku risk seeker terhadap harga atau dengan kata lain petani yang menggunakan teknologi informasi adalah petani risk seeker.
\end{abstract}

Usia petani menunjukkan pengaruh yang positif dan signifikan. Ini artinya adalah petani yang berusia lebih tua berperilaku risk seeker. Petani berusia lebih tua telah berpegalaman dalam mengelola usahataninya dan menggunakan pengalamannya untuk memprediksi dan menangani fluktuasi harga. Petani di lokasi penelitian adalah petani yang turun temurun atau petani yang mewarisi profesi sebagai petani dari nenek moyangnya. Jadi semakin berumur petani semakin berpengalaman sehingga mereka memiliki kemampuan untuk menangani ketidakpastian pasar. Beberapa penelitian yang menjelaskan adanya pengaruh positif dan signifikan antara usia dengan sikap terhadap risiko antara lain Ahmad, et al. (2019); Aldosari, et al. (2017); Lobos, et al. (2018).

Harga kentang sebelumnya adalah harga kentang pada saat panen sebelumnya. Pengambilan data dilakukan saat musim penghujan sehingga rata-rata harga turun. Harga sebelumnya lebih tinggi yaitu ratarata Rp. 7000/kg dan harga pada saat panen terakhir rata-rata Rp. 6000. Pengaruh harga kentang sebelumnya terhadap perilaku risiko harga adalah positif dan signifikan. Ini artinya jika harga kentang tinggi maka sikap petani akan mengambil risiko harga (risk seeker). Sebaliknya jika harga rendah petani akan berperilaku risk averse. Ini berlaku juga untuk harga saat ini.

Koefisien menunjukkan positif dan sigifikan. Dari dua faktor ini menunjukkan bahwa petani kentang berharap bahwa harga kentang tetap tinggi. Jika harga turun maka petani 
akan menolak risiko dan akan berpengaruh terhadap cara mengelola usahataninya. Beberapa petani yang risk averse mulai meninggalkan usahatani kentang beralih kepada komoditi lain yang lebih menguntungkan. Ini bisa dimengerti karena modal untuk berusahatani kentang sangat besar yaitu rata-rata Rp. 60.000.000 - Rp. 75.000/ha.

Koefisien variabel pekerjaan di luar pertanian menunjukkan pengaruh negatif namun tidak berpengaruh. Pekerjaan di luar pertanian dilakukan sebagai pekerjaan sampingan. Koefisien yang negatif bisa diartikan bahwa petani yang memiliki pekerjaan di luar pertanian adalah petani yang bersikap risk averse. Petani mencoba mencari pendapatan lain untuk cadangan jika terjadi kerugian di pekerjaan pertanian. Jika pekerjaan di luar pertanian ini dilakukan sungguhsungguh dan didukung oleh anggota keluarga maka tidak mungkin akan membantu petani dalam menangani fluktuasi harga. Sujarwo, et al., 2017 dalam penelitiannya menjelaskan bahwa keluarga petani yang memiliki sumber pendapatan lebih banyak akan lebih kuat dalam menghadapi ririko dan ketidakpastian. Tingkat keengganan terhadap risiko akan lebih kecil. Lebih lanjut Addey (2018) menjelaskan bahwa rasio pekerjaan off farm dan on farm secara signifikan mempengaruhi proposalitas kenetralan petani dalam bersikap terhadap resiko.

Tabel 4 juga menunjukkan kemampuan model logit yang ditetapkan sebesar $88 \%$ benar dalam memprediksi petani yang risk averse dan $87,9 \%$ untuk petani risk seeker.

Tabel 4. Hasil estimasi Overall Percentage dan Nagelkerke R Square

\begin{tabular}{llcccc}
\hline \multirow{2}{*}{ Yang Diamati } & \multicolumn{4}{c}{ Yang Diduga/Diramal } \\
\cline { 3 - 6 } & & 0 & \multicolumn{2}{c}{ Correct } \\
\cline { 2 - 6 } Risiko harga & 0 & 81 & 11 & 88.000 & \\
& 1 & 11 & 80 & 87.900 & 88.000 \\
Overall Percentage & & & & & 0.762 \\
Nagelkerke R Square & & \multicolumn{5}{c}{}
\end{tabular}

Sumber: Analisis Data 2018 


\begin{abstract}
Hasil penelitian ini memperlihatkan bahwa untuk menghadapi risiko harga yang terjadi pada usahatani, maka petani dapat mengoptimalkan penggunaan teknologi informasi yang dikuasai. Ketrampilan dan teknis penggunaan teknologi informasi selalu di ditingkatkan dengan mengikuti pelatihan dan selalu menjalin komunikasi antar anggota kelompok tani. Teknologi informasi selain untuk mendapatkan informasi budidaya juga di optimalkan untuk selalu memperbaharui informasi tentang harga.
\end{abstract}

\section{KESIMPULAN}

Persepsi petani terhadap teknologi informasi dipengaruhi oleh lokasi penelitian yang bertopografi berbukit dengan kemiringan lahan yang terjal. Persepsi petani teknologi informasi bermanfaat dalam kegiatan usatani kentang. Petani menggunakan teknologi informasi untuk mendapatkan informasi tentang harga dan pasar.

Terdapat faktor yang positif dan signifikan mempengaruhi penerimaan risiko harga (risk seeker) yaitu usia, harga kentang sebelumnya, harga saat ini dan penggunaan teknologi informasi. Dari keempat faktor tersebut, penggunaan teknologi informasi memberikan pengaruh tertinggi dalam kemungkinan penerimaan terhadap risiko harga.

Koefisien variabel pekerjaan di luar pertanian menunjukkan pengaruh negatif namun tidak signifikan.

\section{DAFTAR PUSTAKA}

Addey, K. A. 2018. Determinants of Rice Farmers' Risk-Attitudes in Rural Ghana: an Operational Domain Scale Approach. Journal of Agricultural Studies. 6 (1): 116-130.

Ahmad, D., M. Afzal. \& A. Rauf. 2019. Analysis of Wheat Farmers' Risk Perceptions and Attitudes: Evidence from Punjab. Pakistan. Natural Hazards. 95 (3): 845-861.

Aldosari, F., M.S. Al Shunaifi, M.A Ullah, M. Muddassir \& M.A Noor. 2017. Farmers' Perceptions Regarding the Use of Information and Communication Technology (ICT) in Khyber Pakhtunkhwa, Northern Pakistan. Journal of the Saudi Society of Agricultural Sciences.

Amin, M. 2016. Efektivitas an Perilaku Petani dalam 
Memanfaatkan Teknologi Informasi Berbasis Teknologi Informasi. Informatika

Pertanian. 23 (2): 211-219.

Burman, R. R., S.K. Dubey, J.P. Sharma, K. Vijayaragavan, V. Sangeetha, \& I. Singh. 2013. Information Dynamics for Designing Teknologi Informasi Model for Agricultural Development. Journal of Community Mobilization and Sustainable Development. 8 (2): 182-185.

Dasli, A. P. E., P. Muljono \& D. Susanto. 2015. Pemanfaatan Teknologi Informasi Melalui Telepon Genggam oleh Petani Anggrek di Taman Anggrek Ragunan, Jakarta Selatan. Jurnal Penyuluhan. 11 (2).

Duong, T., T. Brewer, J. Luck \& K. Zander. 2019. A Global Review of Farmers' Perceptions of Agricultural Risks and Risk Management Strategies. Agriculture. 9(1): 10.

Fangohoi, L., S. Sugiyanto, K. Sukesi, \& E. D. Cahyono. 2018. Establish the Perception of Agricultural Extension Workers Through Teknologi Informasi as the Media Information. Journal of Socioeconomics and Development. 1 (1): 32-37.

Kimura, S., J. Antón \& C. LeThi. 2010. Farm Level Analysis of Risk and Risk Management Strategies and Policies.
Lobos, G., B. Schnettler, C. Mena, Y. Ormazábal, J.C. Cantillana \& J.B. Retamales. 2018. Perception of Risk Sources by Chilean Blueberry Producers. Revista Brasileira de Fruticultura. 40 (6).

Sujarwo, S. 2017. Factors Affecting Farmers'acceptability toward Agricultural Insurance Program in Malang, East Java, Indonesia. Agricultural SocioEconomics Journal. 17(3): 97104. 